Research Article

\title{
Heat Capacity and Thermodynamic Properties of Cesium Pentaborate Tetrahydrate
}

\author{
Kangrui Sun, Panpan Li, Long Li, Yafei Guo $(\mathbb{D}$, and Tianlong Deng $(1)$ \\ Tianjin Key Laboratory of Marine Resources and Chemistry, College of Chemical Engineering and Materials Science, \\ Tianjin University of Science and Technology, Tianjin 300457, China
}

Correspondence should be addressed to Yafei Guo; guoyafei@tust.edu.cn and Tianlong Deng; tldeng@tust.edu.cn

Received 24 October 2019; Revised 30 November 2019; Accepted 6 December 2019; Published 28 February 2020

Academic Editor: João Paulo Leal

Copyright (c) 2020 Kangrui Sun et al. This is an open access article distributed under the Creative Commons Attribution License, which permits unrestricted use, distribution, and reproduction in any medium, provided the original work is properly cited.

\begin{abstract}
This paper reports the molar heat capacities of $\beta-\mathrm{CsB}_{5} \mathrm{O}_{8} \cdot 4 \mathrm{H}_{2} \mathrm{O}$, which were measured by an accurate adiabatic calorimeter from 298 to $373 \mathrm{~K}$ with a heating rate of $0.1 \mathrm{~K} / \mathrm{min}$ under nitrogen atmosphere. Neither phase transition nor thermal anomalies were observed. The molar heat capacity against temperature was fitted to a polynomial equation of $C_{p, m}\left(\mathrm{~J} \cdot \mathrm{mol}^{-1} \cdot \mathrm{K}^{-1}\right)=$ $\left.618.07702+39.52669\left[T-\left(T_{\max }+T_{\min }\right) / 2\right] /\left(T_{\max }-T_{\min }\right) / 2\right]-3.46888\left[\left(T-\left(T_{\max }+T_{\min }\right) / 2\right) /\left(T_{\max }-T_{\min }\right) / 2\right]^{2}+7.9441\left[\left(T-\left(T_{\max }+\right.\right.\right.$ $\left.\left.\left.T_{\min }\right) / 2\right) /\left(T_{\max }-T_{\min }\right) / 2\right]^{3}$. The relevant thermodynamic functions of enthalpy $\left(H_{T}-H_{298.15}\right)$, entropy $\left(S_{T}-S_{298.15}\right)$, and Gibbs free energy $\left(G_{T}-G_{298.15}\right)$ of cesium pentaborate tetrahydrate from 298 to $375 \mathrm{~K}$ of $5 \mathrm{~K}$ intervals are also obtained on the basis of relational expression equations between thermodynamic functions and the molar heat capacity.
\end{abstract}

\section{Introduction}

Boron and borates are considered as a kind of modern strategic resource worldwide for high melting point, high hardness, high strength, light weight, and abrasion resistance, and they are extensively applied in whisker materials, superconducting materials, fuel-rich propellants, and other high-technology domains [1-4]. Nowadays, the continuously increasing demand for cesium borates owing to the significant physical interest [5], along with their limited production, has led to a situation where the supply fails to meet the market demand. A number of salt lakes with an abundance of boron resources are widely distributed in the western regions of China, and studies on thermodynamic properties are of great importance not only in guiding the comprehensive utilization of the resources but also in evaluating and explaining the corresponding physicochemical properties, as well as exploring novel methods for more effective and efficient extraction for salt lake resources. Hence, in order to provide useful information for extracting cesium borates and synthesizing materials, it is highly desirable to study the thermodynamic properties.

The thermodynamic properties for borates or its aqueous solutions have attracted great attention in these past few years, including the enthalpy of dilution [6], the molar heat capacity [7-10], the apparent molar volumes $[11,12]$, and the standard molar enthalpies of formation [13-15]. Heat capacity is one of the more valuable thermophysical quantities and reflects the ability of a substance to absorb or release heat without phase transition. Cui et al. [7] reported the heat capacity of lithium pentaborate pentahydrate using an adiabatic calorimeter at the temperature from 297 to $375 \mathrm{~K}$, and relevant thermodynamic functions were obtained at the temperature of $5 \mathrm{~K}$ intervals. And the heat capacities and thermodynamic functions of the aqueous $\mathrm{Li}_{2} \mathrm{~B}_{4} \mathrm{O}_{7}$ solution were measured at a concentration of 0.0187 and $0.3492 \mathrm{~mol} \cdot \mathrm{kg}^{-1}$ from 80 to $355 \mathrm{~K}[8,9]$. In addition, the heat capacity of cesium tetraborate pentahydrate has been measured with the high-precision TG-DSC LABSYS Evo in the range of 303 to $349 \mathrm{~K}$ [10]. However, up to now, there are no data reported on the heat capacity of cesium pentaborate 
tetrahydrate. In this paper, the heat capacity and the related thermodynamic functions of enthalpy, entropy, and Gibbs free energy for $\beta$ - $\mathrm{CsB}_{5} \mathrm{O}_{8} \cdot 4 \mathrm{H}_{2} \mathrm{O}$ have been determined for the first time.

\section{Experimental}

2.1. Materials. The purity degree and purification of the chemicals used in this work are tabulated in Table 1. The doubly deionized water (DDW) produced by ULUP-II-10T (Chongqing Jiuyang Co. Ltd., China) with a conductivity less than $1 \times 10^{-4} \mathrm{~S} \cdot \mathrm{m}^{-1}$ and $\mathrm{pH} \approx 6.60$ at $25^{\circ} \mathrm{C}$, was used during the whole experiment. On the basis of the method described in the literature [16], $\beta-\mathrm{CsB}_{5} \mathrm{O}_{8} \cdot 4 \mathrm{H}_{2} \mathrm{O}$ was successfully synthesized in our laboratory. A certain amount of $\mathrm{Cs}_{2} \mathrm{CO}_{3}$ was added to a solution of $\mathrm{H}_{3} \mathrm{BO}_{3}$, in which the molar ration of $\mathrm{Cs}_{2} \mathrm{CO}_{3}: \mathrm{H}_{3} \mathrm{BO}_{3}$ is $1: 10$, followed by stirring at room temperature for homogeneity, and heated to the boiling point for releasing $\mathrm{CO}_{2}$. Then, the solution was stirred at $60^{\circ} \mathrm{C}$ for $24 \mathrm{~h}$ to precipitate out of the solid phase. Finally, the precipitates were filtered, recrystallized, washed with DDW as well as absolute ethyl alcohol separately, and dried at $30^{\circ} \mathrm{C}$ to obtain the samples. In addition, the samples were dried at $50^{\circ} \mathrm{C}$ and atmospheric pressure until the weight was constant, and then cooled down to room temperature to store in the desiccators for use.

2.2. Characterization. The synthesized $\mathrm{CsB}_{5} \mathrm{O}_{8} \cdot 4 \mathrm{H}_{2} \mathrm{O}$ was identified by the X-ray diffractometer (MSAL XD-3, Beijing Purkinje Instrument Co. Ltd., China) with $\mathrm{Cu}-\mathrm{K} \alpha$ radiation at $4 \mathrm{~min}^{-1}$ in the scan range of $2 \theta$ from 5 to $70^{\circ}$, and the results are shown in Figure 1 and it can clearly be seen that the peak position and intensity of the synthesized $\mathrm{CsB}_{5} \mathrm{O}_{8} \cdot 4 \mathrm{H}_{2} \mathrm{O}$ were in great agreement with the standard map (22-0175), indicating that the compound for $\mathrm{CsB}_{5} \mathrm{O}_{8} \cdot 4 \mathrm{H}_{2} \mathrm{O}$ is the beta phase $\left(\beta-\mathrm{CsB}_{5} \mathrm{O}_{8} \cdot 4 \mathrm{H}_{2} \mathrm{O}\right)$ [16]. TG and DSC were conducted by SETARAM LABSYS thermal analyzer under an $\mathrm{N}_{2}$ atmosphere with a heating rate of $10 \mathrm{~K} \cdot \mathrm{min}^{-1}$ from 298.15 to $823.15 \mathrm{~K}$, as shown in Figure 2. Furthermore, the output of water molecules proceeds in two stages [17]. The first stage is observed from $393 \mathrm{~K}$ to $473 \mathrm{~K}$ with a loss of three water molecules and the compound transforms into the amorphous, and the second stage is observed with the loss of only one water molecule. The total weight loss of the sample was 0.1863 in mass fraction, which is essentially consistent with the theoretical value of 0.1862 , the deviation being only $0.05 \%$.

The concentration of $\mathrm{B}_{2} \mathrm{O}_{3}$ was determined by the mannitol gravimetric method with a known content of $\mathrm{NaOH}$ aqueous solution in the presence of double indicator of methyl red and phenolphthalein with the standard uncertainty of 0.0005 in mass fraction [18], and the reaction equation can be written as follows. The content for cesium ion was measured by inductively coupled plasma optical emission spectrometer (Prodigy, Leman Corporation, America) with a precision of \pm 0.005 in mass fraction. The $\mathrm{H}_{2} \mathrm{O}$ content was calculated through differential subtraction and the calculated value of $18.63 \%$ corresponds to the four water molecules. The chemical analysis results presented in Table 2, together with the X-ray diffractometer map and TG analysis, testify that the purity of the synthesized $\beta-\mathrm{CsB}_{5} \mathrm{O}_{8} \cdot 4 \mathrm{H}_{2} \mathrm{O}$ reaches 0.995 in mass fraction:

$$
\begin{array}{r}
\mathrm{H}_{3} \mathrm{BO}_{3}+\mathrm{C}_{6} \mathrm{H}_{14} \mathrm{O}_{6} \longrightarrow \mathrm{C}_{6} \mathrm{H}_{8}(\mathrm{OH})_{2} \cdot\left(\mathrm{BO}_{3} \mathrm{H}\right)_{2}+4 \mathrm{H}_{2} \mathrm{O} \\
\mathrm{C}_{6} \mathrm{H}_{8}(\mathrm{OH})_{2} \cdot\left(\mathrm{BO}_{3} \mathrm{H}\right)_{2}+\mathrm{NaOH} \longrightarrow \mathrm{C}_{6} \mathrm{H}_{8}(\mathrm{OH})_{2} \cdot\left(\mathrm{BO}_{3} \mathrm{Na}\right)_{2}+4 \mathrm{H}_{2} \mathrm{O}
\end{array}
$$

2.3. Apparatus and Procedure. A high-precision adiabatic microcalorimeter (BT2.15, SETARAM, France), which mainly comprised a calorimetric chamber, electrical or pneumatic peripherals, and the liquid nitrogen supply, was employed for measuring the heat capacity of $\beta-\mathrm{CsB}_{5} \mathrm{O}_{8} \cdot 4 \mathrm{H}_{2} \mathrm{O}$ over the temperature range of 298 to $373 \mathrm{~K}$ with a heating rate of $0.1 \mathrm{~K} / \mathrm{min}$ under nitrogen atmosphere and the sample mass in the sample cell used for the heat capacity measurement was $16044.01 \mathrm{mg}$ weighted with an accuracy of $0.00001 \mathrm{~g}$. To verify the accuracy of the calorimeter, the heat capacity of a reference standard material $(\mathrm{KCl})$ was carried out at $298.15 \mathrm{~K}$ where the average result is $0.6876 \mathrm{~J} \cdot \mathrm{g}^{-1} \cdot \mathrm{K}^{-1}$ for seven times, which agrees well with $0.6879 \mathrm{~J} \cdot \mathrm{g}^{-1} \cdot \mathrm{K}^{-1}$, reported in the literature [19], and the deviation is 0.0004 .

\section{Results and Discussion}

3.1. Heat Capacity. The values for the molar heat capacity of $\beta-\mathrm{CsB}_{5} \mathrm{O}_{8} \cdot 4 \mathrm{H}_{2} \mathrm{O}$ measured by the adiabatic calorimeter from
298 to $373 \mathrm{~K}$ with the standard uncertainty of $0.05 \mathrm{~J} \cdot \mathrm{mol}^{-1} \cdot \mathrm{K}^{-1}$ are listed in Table 3 and plotted in Figure 3. As shown in Figure 3 , the heat capacities of $\beta-\mathrm{CsB}_{5} \mathrm{O}_{8} \cdot 4 \mathrm{H}_{2} \mathrm{O}$ increase slowly in the rise of temperature from 298 to $373 \mathrm{~K}$, which shows that the structure of $\beta-\mathrm{CsB}_{5} \mathrm{O}_{8} \cdot 4 \mathrm{H}_{2} \mathrm{O}$ is stable in this temperature region, that is, no phase transition is observed and no other thermal anomalies take place within the temperature range of the experiment. Compared with the $\mathrm{Cs}_{2} \mathrm{~B}_{4} \mathrm{O}_{7} \cdot 5 \mathrm{H}_{2} \mathrm{O}$ as well as $\mathrm{LiB}_{5} \mathrm{O}_{8} \cdot 5 \mathrm{H}_{2} \mathrm{O}[7,10]$, the molar heat capacity of $\beta-\mathrm{CsB}_{5} \mathrm{O}_{8} \cdot 4 \mathrm{H}_{2} \mathrm{O}$ is much larger than that of $\mathrm{Cs}_{2} \mathrm{~B}_{4} \mathrm{O}_{7} \cdot 5 \mathrm{H}_{2} \mathrm{O}$ from 303 to $335 \mathrm{~K}$, and that of $\mathrm{LiB}_{5} \mathrm{O}_{8} \cdot 5 \mathrm{H}_{2} \mathrm{O}$ is smaller than that of $\mathrm{Cs}_{2} \mathrm{~B}_{4} \mathrm{O}_{7} \cdot 5 \mathrm{H}_{2} \mathrm{O}$ and $\beta-\mathrm{CsB}_{5} \mathrm{O}_{8} \cdot 4 \mathrm{H}_{2} \mathrm{O}$ at the same temperature. For $\beta-\mathrm{CsB}_{5} \mathrm{O}_{8} \cdot 4 \mathrm{H}_{2} \mathrm{O}$ and $\mathrm{Cs}_{2} \mathrm{~B}_{4} \mathrm{O}_{7} \cdot 5 \mathrm{H}_{2} \mathrm{O}$, the types of elements are the same including the cesium, boron, hydrogen, and oxygen, and the distinction in the heat capacity may be caused by the diverse internal structures of the molecules. However, for $\beta-\mathrm{CsB}_{5} \mathrm{O}_{8} \cdot 4 \mathrm{H}_{2} \mathrm{O}$ and $\mathrm{LiB}_{5} \mathrm{O}_{8} \cdot 5 \mathrm{H}_{2} \mathrm{O}$, cesium and lithium belong to the same group and the radius of cesium ion is larger than that of lithium ion, resulting in more electrons around the cesium 
TABLE 1: Reagents used in the study.

\begin{tabular}{|c|c|c|c|c|c|}
\hline Chemicals & $\begin{array}{c}\text { CAS reg. } \\
\text { no. }\end{array}$ & $\begin{array}{c}\text { Initial mass fraction } \\
\text { purity }\end{array}$ & Purification method & $\begin{array}{c}\text { Final mass fraction } \\
\text { purity }\end{array}$ & Analysis method \\
\hline $\mathrm{H}_{3} \mathrm{BO}_{3}{ }^{\mathrm{a}}$ & $10043-35-3$ & 0.9999 & $\begin{array}{c}\text { Without } \\
\text { purification }\end{array}$ & 0.9999 & Gravimetric method for boron \\
\hline $\mathrm{CsCO}_{3}{ }^{\mathrm{b}}$ & $534-17-8$ & 0.9990 & $\begin{array}{l}\text { Without } \\
\text { purification }\end{array}$ & 0.9990 & $\begin{array}{l}\text { Gravimetric method for } \\
\text { carbonate }\end{array}$ \\
\hline$\beta-\mathrm{CsB}_{5} \mathrm{O}_{8} \cdot 4 \mathrm{H}_{2} \mathrm{O}^{\mathrm{c}}$ & - & 0.9900 & Recrystallization & 0.9950 & Gravimetric method for boron \\
\hline
\end{tabular}

${ }^{a}$ From the Shanghai Macklin Biochemical Co. Ltd. ${ }^{b}$ From the Aladdin Industrial Co. Ltd. ${ }^{c}$ Synthesized in our laboratory.

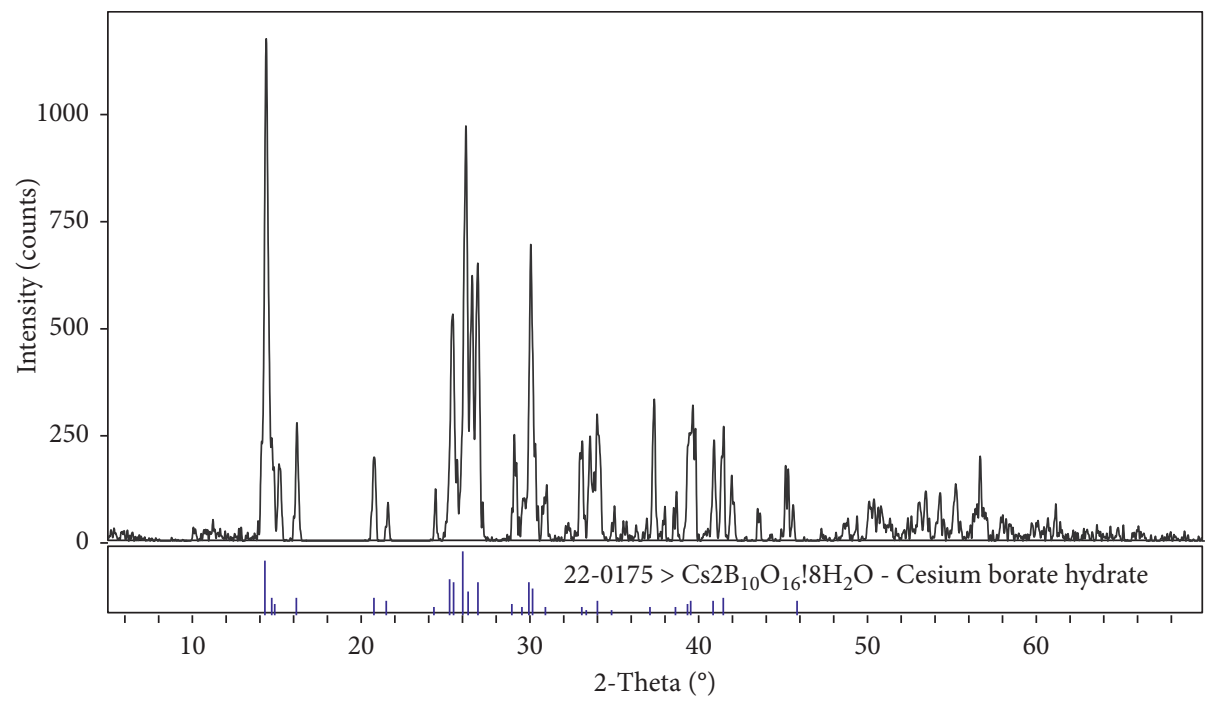

Figure 1: The X-ray diffraction pattern of $\beta-\mathrm{CsB}_{5} \mathrm{O}_{8} \cdot 4 \mathrm{H}_{2} \mathrm{O}$.

ion, which leads to the difference of the energy when the temperature varies and further causes the imparity of heat capacity. Therefore, the molar heat capacities of $\mathrm{Cs}_{2} \mathrm{~B}_{4} \mathrm{O}_{7} \cdot 5 \mathrm{H}_{2} \mathrm{O}$ and $\beta-\mathrm{CsB}_{5} \mathrm{O}_{8} \cdot 4 \mathrm{H}_{2} \mathrm{O}$ are larger than that of $\mathrm{LiB}_{5} \mathrm{O}_{8} \cdot 5 \mathrm{H}_{2} \mathrm{O}$.
In order to obtain the heat capacity quickly at a certain temperature, the molar heat capacity of $\beta-\mathrm{CsB}_{5} \mathrm{O}_{8} \cdot 4 \mathrm{H}_{2} \mathrm{O}$ determined in this work has been fitted by means of a leastsquares method and the polynomial equation with the correlation coefficient $r=0.99722$ can be expressed as follows:

$$
\begin{aligned}
C_{p, m}\left(\mathrm{~J} \cdot \mathrm{mol}^{-1} \cdot K^{-1}\right)= & 618.07702+39.52669 \frac{\left[T-\left(\left(T_{\max }+T_{\min }\right) / 2\right)\right]}{\left[\left(T_{\max }-T_{\min }\right) / 2\right]} \\
& -3.46888\left\{\frac{\left[T-\left(\left(T_{\max }+T_{\min }\right) / 2\right)\right]}{\left[\left(T_{\max }-T_{\min }\right) / 2\right]}\right\}^{2} \\
& +7.9441\left\{\frac{\left[T-\left(\left(T_{\max }+T_{\min }\right) / 2\right)\right]}{\left[\left(T_{\max }-T_{\min }\right) / 2\right]}\right\}^{3},
\end{aligned}
$$

where $C_{p, m}$ is the molar heat capacity of $\beta-\mathrm{CsB}_{5} \mathrm{O}_{8} \cdot 4 \mathrm{H}_{2} \mathrm{O}$ $\left(\mathrm{J} \cdot \mathrm{mol}^{-1} \cdot \mathrm{K}^{-1}\right), T$ is the thermodynamic temperature $(\mathrm{K})$, and $T_{\max }$ and $T_{\min }$ are the maximum and minimum in the experimental temperature range, which are 373.01 and 298.02 K, respectively. According to the above equation, the molar heat capacity of $\beta-\mathrm{CsB}_{5} \mathrm{O}_{8} \cdot 4 \mathrm{H}_{2} \mathrm{O}$ at $298.15 \mathrm{~K}$ can be calculated as $567.37 \mathrm{~J} \cdot \mathrm{mol}^{-1} \cdot \mathrm{K}^{-1}$, and the standard deviations between experimental values, $C_{p \text {,exp }}$, and fitted values $C_{p \text {, fit }}$ through the polynomial equation are within 0.005 , as shown in Figure 4.

3.2. Thermodynamic Functions. Thermodynamic functions $\left(H_{T}-H_{298.15}\right), \quad\left(S_{T}-S_{298.15}\right), \quad$ and $\quad\left(G_{T}-G_{298.15}\right)$ of 


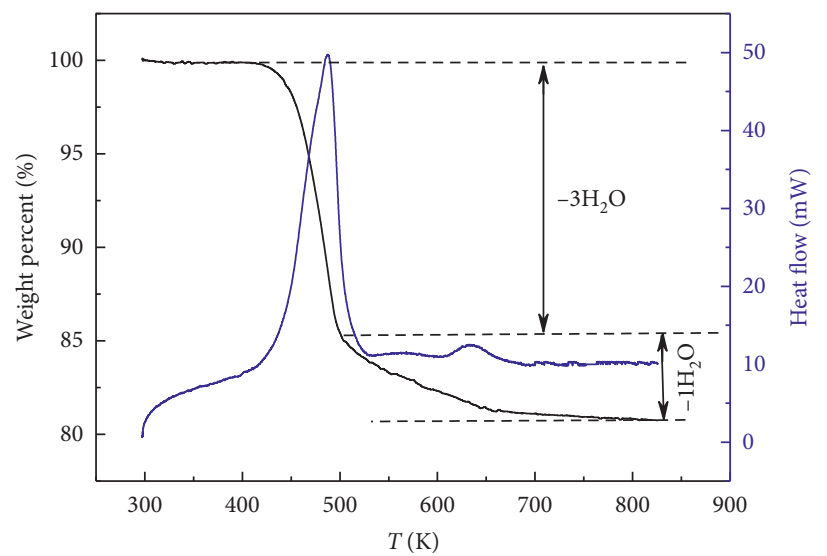

Figure 2: The TG and DSC curve of $\beta-\mathrm{CsB}_{5} \mathrm{O}_{8} \cdot 4 \mathrm{H}_{2} \mathrm{O}$.

TABLE 2: Chemical analytical results of $\beta-\mathrm{CsB}_{5} \mathrm{O}_{8} \cdot 4 \mathrm{H}_{2} \mathrm{O}$ in mass fraction ${ }^{\mathrm{a}}$.

\begin{tabular}{lcccc}
\hline $\mathrm{CsB}_{5} \mathrm{O}_{8} \cdot 4 \mathrm{H}_{2} \mathrm{O}$ & $\mathrm{Cs}_{2} \mathrm{O}$ & $\mathrm{B}_{2} \mathrm{O}_{3}$ & $\mathrm{H}_{2} \mathrm{O}$ & $n\left(\mathrm{Cs}_{2} \mathrm{O}: \mathrm{B}_{2} \mathrm{O}_{3}: \mathrm{H}_{2} \mathrm{O}\right)$ \\
\hline Experimental & 0.3663 & 0.4474 & 0.1863 & $1.00: 4.94: 7.96$ \\
Theoretical & 0.3641 & 0.4497 & 0.1862 & $1.00: 5.00: 8.00$ \\
Relative error (\%) & 0.60 & 0.50 & 0.05 & - \\
\hline
\end{tabular}

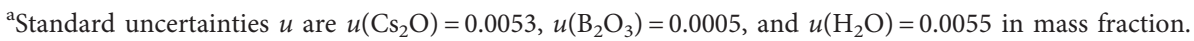

TABLe 3: Molar heat capacity of $\beta-\mathrm{CsB}_{5} \mathrm{O}_{8} \cdot 4 \mathrm{H}_{2} \mathrm{O}$ (molecular mass $M=386.95 \mathrm{~g} \cdot \mathrm{mol}^{-1}$ ).

\begin{tabular}{|c|c|c|c|c|c|}
\hline$T(\mathrm{~K})^{\mathrm{a}}$ & $C_{p, m}\left(\mathrm{~J} \cdot \mathrm{mol}^{-1} \cdot \mathrm{K}^{-1}\right)$ & $T(\mathrm{~K})$ & $C_{p, m}\left(\mathrm{~J} \cdot \mathrm{mol}^{-1} \cdot \mathrm{K}^{-1}\right)$ & $T(\mathrm{~K})$ & $C_{p, m}\left(\mathrm{~J} \cdot \mathrm{mol}^{-1} \cdot \mathrm{K}^{-1}\right)$ \\
\hline 298.02 & 565.49 & 324.04 & 606.12 & 350.01 & 632.08 \\
\hline 299.01 & 567.42 & 325.05 & 607.88 & 351.01 & 634.06 \\
\hline 300.01 & 569.35 & 326.00 & 608.30 & 352.04 & 635.99 \\
\hline 301.06 & 571.66 & 327.01 & 609.28 & 353.00 & 636.81 \\
\hline 302.01 & 573.85 & 328.02 & 609.80 & 354.06 & 638.94 \\
\hline 303.05 & 575.71 & 329.08 & 610.97 & 355.02 & 640.93 \\
\hline 304.00 & 577.75 & 330.06 & 612.01 & 356.04 & 642.12 \\
\hline 305.01 & 579.77 & 331.04 & 612.25 & 357.04 & 643.19 \\
\hline 306.01 & 581.49 & 332.00 & 614.00 & 358.04 & 644.83 \\
\hline 307.07 & 583.69 & 333.00 & 614.71 & 359.01 & 646.08 \\
\hline 308.01 & 585.50 & 334.01 & 615.94 & 360.03 & 647.90 \\
\hline 309.01 & 586.48 & 335.00 & 616.34 & 361.08 & 648.30 \\
\hline 310.06 & 588.54 & 336.04 & 617.34 & 362.07 & 649.39 \\
\hline 311.06 & 590.00 & 337.08 & 618.49 & 363.04 & 650.39 \\
\hline 312.02 & 591.22 & 338.05 & 619.12 & 364.03 & 651.17 \\
\hline 313.10 & 592.50 & 338.97 & 620.37 & 365.00 & 651.98 \\
\hline 314.01 & 593.08 & 340.02 & 621.15 & 366.05 & 652.52 \\
\hline 315.07 & 593.96 & 341.06 & 622.30 & 367.07 & 653.01 \\
\hline 316.07 & 595.69 & 342.08 & 623.74 & 368.14 & 654.35 \\
\hline 317.01 & 597.06 & 343.05 & 624.55 & 369.21 & 655.23 \\
\hline 318.01 & 598.19 & 344.02 & 625.64 & 370.12 & 656.94 \\
\hline 319.07 & 599.67 & 345.10 & 626.27 & 371.01 & 657.83 \\
\hline 320.03 & 601.75 & 346.01 & 627.05 & 372.02 & 658.27 \\
\hline 321.04 & 602.34 & 347.06 & 628.44 & 373.02 & 659.07 \\
\hline 322.01 & 603.82 & 348.03 & 629.64 & & \\
\hline 323.02 & 604.84 & 349.01 & 631.44 & & \\
\hline
\end{tabular}

${ }^{\mathrm{a}}$ Uncertainty of temperature $u(T)=0.01 \mathrm{~K}$, and the molar heat capacity uncertainty $u\left(\mathrm{C}_{p, m}\right)=0.05 \mathrm{~J} \cdot \mathrm{mol}^{-1} \cdot \mathrm{K}^{-1}$. 


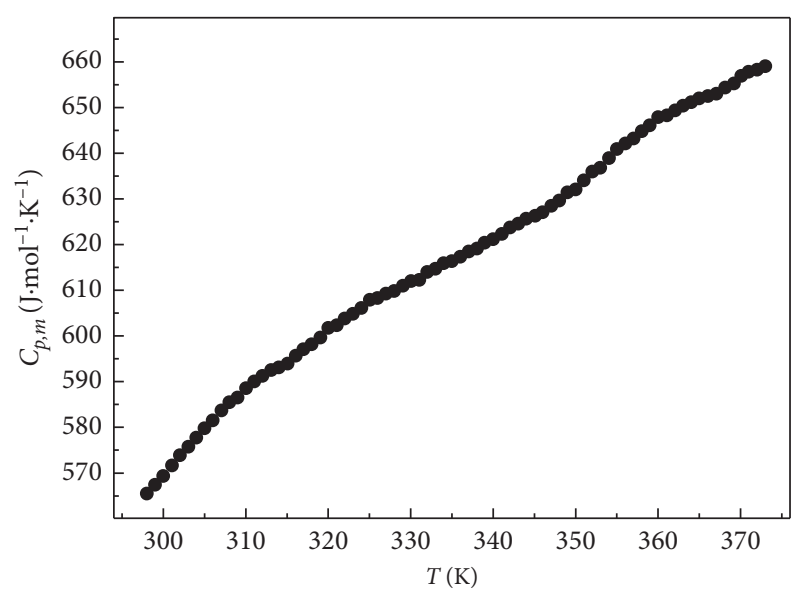

Figure 3: Experimental molar heat capacity of $\beta-\mathrm{CsB}_{5} \mathrm{O}_{8} \cdot 4 \mathrm{H}_{2} \mathrm{O}$ in the range of 298 to $373 \mathrm{~K}$.

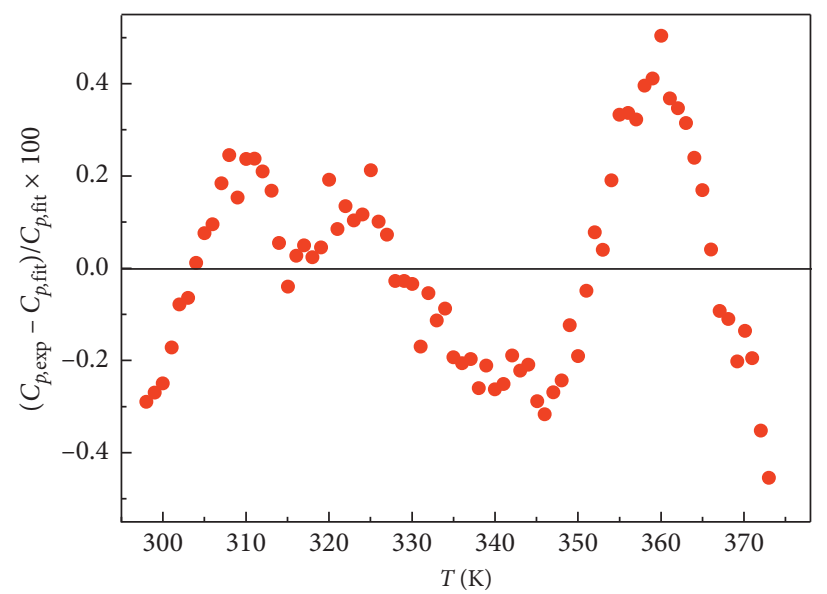

Figure 4: The deviations of the experimental and fitting values.

TABLE 4: Molar heat capacity and thermodynamic functions of $\beta-\mathrm{CsB}_{5} \mathrm{O}_{8} \cdot 4 \mathrm{H}_{2} \mathrm{O}$.

\begin{tabular}{lcccc}
\hline$T(\mathrm{~K})$ & $C_{p, m}\left(\mathrm{~J} \cdot \mathrm{mol}^{-1} \cdot \mathrm{K}^{-1}\right)$ & $H_{T}-H_{298.15}\left(\mathrm{~kJ} \cdot \mathrm{mol}^{-1}\right)$ & $S_{T}-S_{298.15}\left(\mathrm{~J} \cdot \mathrm{mol}^{-1} \cdot \mathrm{K}^{-1}\right)$ & $G_{T}-G_{298.15}\left(\mathrm{~kJ} \cdot \mathrm{mol}^{-1}\right)$ \\
\hline 298.15 & 567.37 & 0.00 & 0.00 & 0.00 \\
300 & 570.77 & -10.46 & 63.61 & -29.55 \\
305 & 579.32 & -37.84 & 233.99 & -109.21 \\
310 & 587.06 & -63.93 & 402.10 & -188.58 \\
315 & 594.10 & -88.77 & 567.93 & -267.67 \\
320 & 600.56 & -112.40 & 731.47 & -346.47 \\
325 & 606.54 & -134.84 & 892.72 & -424.98 \\
330 & 612.16 & -156.15 & 1051.66 & -503.20 \\
335 & 617.53 & -176.35 & 1208.30 & -581.13 \\
340 & 622.76 & -195.48 & 1362.63 & -658.78 \\
345 & 627.98 & -213.57 & 1514.66 & -736.13 \\
350 & 633.28 & -230.66 & 1664.39 & -813.20 \\
355 & 638.79 & -246.78 & 1811.82 & -889.97 \\
360 & 644.62 & -261.96 & 1956.95 & -966.46 \\
365 & 650.87 & -276.23 & 2099.80 & -1042.66 \\
370 & 657.67 & -289.63 & 2240.36 & -1118.56 \\
375 & 665.12 & -302.18 & 2378.66 & -1194.18 \\
\hline
\end{tabular}


$\beta-\mathrm{CsB}_{5} \mathrm{O}_{8} \cdot 4 \mathrm{H}_{2} \mathrm{O}$ relative to the standard status $(298.15 \mathrm{~K}$ and $0.1 \mathrm{MPa}$ ) were obtained according to the following thermodynamic equations:

$$
\begin{aligned}
H_{T}-H_{298.15} & =\int_{298.15}^{T} C_{p, m} \mathrm{~d} T, \\
S_{T}-S_{298.15} & =\int_{298.15}^{T}\left[\frac{C_{p, m}}{T}\right] \mathrm{d} T, \\
G_{T}-G_{298.15} & =\int_{298.15}^{T} C_{p, m} \mathrm{~d} T-T \int_{298.15}^{T}\left[\frac{C_{p, m}}{T}\right] \mathrm{d} T .
\end{aligned}
$$

The polynomial fitted values for the molar heat capacity and thermodynamic functions of $\beta-\mathrm{CsB}_{5} \mathrm{O}_{8} \cdot 4 \mathrm{H}_{2} \mathrm{O}$ are obtained in the temperature range from 298 to $375 \mathrm{~K}$ at intervals of $5 \mathrm{~K}$ and listed in Table 4 . It can clearly be seen that from Table 4 the values of the molar heat capacity and entropy $\left(S_{T}-S_{298.15}\right)$ are increased with the increase of temperature from $298.15 \mathrm{~K}$ to $375 \mathrm{~K}$, but the enthalpy $\left(H_{T}-H_{298.15}\right)$ and Gibbs free energy $\left(G_{T}-G_{298.15}\right)$ are decreased.

\section{Conclusions}

The molar heat capacities of $\beta-\mathrm{CsB}_{5} \mathrm{O}_{8} \cdot 4 \mathrm{H}_{2} \mathrm{O}$ were measured by an adiabatic calorimeter in the temperature range from 298 to $373 \mathrm{~K}$ with a heating rate of $0.1 \mathrm{~K} / \mathrm{min}$ without the phase transition and other thermal anomalies and were fitted to a polynomial equation of $C_{p, m}\left(\mathrm{~J} \cdot \mathrm{mol}^{-1} \cdot \mathrm{K}^{-1}\right)=$ $\left.618.07702+39.52669\left[T-\left(T_{\max }+T_{\min }\right) / 2\right] /\left(T_{\max }-T_{\min }\right) / 2\right]-$ $3.46888\left[\left(T-\left(T_{\max }+T_{\min }\right) / 2\right) /\left(T_{\max }-T_{\min }\right) / 2\right]^{2}+7.9441[(T-$ $\left.\left.\left(T_{\max }+T_{\min }\right) / 2\right) /\left(T_{\max }-T_{\min }\right) / 2\right]^{3}$. The relevant thermodynamic functions of enthalpy, entropy, and Gibbs free energy of cesium pentaborate tetrahydrate are also obtained at intervals of $5 \mathrm{~K}$ from 298 to $375 \mathrm{~K}$.

\section{Data Availability}

The data used to support the findings of this study are available from the corresponding author upon request.

\section{Conflicts of Interest}

The authors declare that they have no conflicts of interest.

\section{Acknowledgments}

Financial supports from the National Natural Science Foundation of China (21773170 and U1607123), the Key Projects of Natural Science Foundation of Tianjin (18JCZDJC10040), and the Yangtze Scholars and Innovative Research Team in Chinese University (IRT_17R81) are acknowledged.

\section{References}

[1] D. L. Shen, X. P. Yu, Y. F. Guo, S. Q. Wang, and T. L. Deng, "Boron and its compounds in new energy and materials fields," Applied Mechanics and Materials, vol. 71-78, pp. 2594-2597, 2011.
[2] J. Peng, S. Bian, B. Zhang, Y. Dong, and W. Li, "Research on boron recovery from sulfate-type saline lakes with a novel dilution method," Hydrometallurgy, vol. 174, pp. 47-55, 2017.

[3] Y. Bing, G. S. Wang, and Y. W. Tian, "Research process of rare earth borate luminescent materials," Materials Review, vol. 1, pp. 34-37, 2013.

[4] B. L. Liu, D. Liu, H. F. Ji, W. D. Wang, and H. L. Xu, "Development of borate functional materials," Guangzhou Chemical Industry, vol. 42, pp. 12-14, 2014.

[5] X. R. Zhang, S. X. Zhang, and Y. Chai, "Study on new nonlinear optical crystal-cesium lithum borate," Journal of Synthetic Crystals, vol. 27, pp. 26-30, 1998.

[6] G. Yin, Y. Yao, B. Jiao, S. Chen, and S. Gao, "Enthalpies of dilution of aqueous $\mathrm{Li}_{2} \mathrm{~B}_{4} \mathrm{O}_{7}$ solutions at $298.15 \mathrm{~K}$ and application of ion-interaction model," Thermochimica Acta, vol. 435, no. 2, pp. 125-128, 2005.

[7] W. Cui, L. Li, Y. Guo, S. Zhang, and T. Deng, "Heat capacity and thermodynamic property of lithium pentaborate pentahydrate," Journal of Chemistry, vol. 2018, Article ID 7962739, 4 pages, 2018.

[8] Z.-H. Zhang, Z.-C. Tan, G. Y. Yin, Y. Yao, L.-X. Sun, and Y.-S. Li, "Heat capacities and thermodynamic functions of the aqueous $\mathrm{Li}_{2} \mathrm{~B}_{4} \mathrm{O}_{7}$ solution in the temperature range from $80 \mathrm{~K}$ to $355 \mathrm{~K}$," Journal of Chemical \& Engineering Data, vol. 52, no. 3, pp. 866-870, 2007.

[9] Z.-H. Zhang, G.-Y. Yin, Z.-C. Tan, Y. Yao, and L.-X. Sun, "Heat capacities and thermodynamic properties of a $\mathrm{H}_{2} \mathrm{O}+\mathrm{Li}_{2} \mathrm{~B}_{4} \mathrm{O}_{7}$ solution in the temperature range from 80 to $356 \mathrm{~K}$," Journal of Solution Chemistry, vol. 35, no. 10, pp. 1347-1355, 2006.

[10] K. Sun, K. Zhao, L. Li, Y. Guo, and T. Deng, "Heat capacity and thermodynamic property of cesium tetraborate pentahydrate," Journal of Chemistry, vol. 2019, Article ID 9371328, 5 pages, 2019.

[11] Y. Guo, K. Zhao, L. Li et al., "Volumetric properties of aqueous solution of lithium tetraborate from 283.15 to $363.15 \mathrm{~K}$ at $101.325 \mathrm{kPa}$," The Journal of Chemical Thermodynamics, vol. 120, pp. 151-156, 2018.

[12] K. Zhao, L. Li, Y. Guo et al., "Apparent molar volumes of aqueous solutions of lithium pentaborate from 283.15 to $363.15 \mathrm{~K}$ and $101.325 \mathrm{kPa}$ : an experimental and theoretical study," Journal of Chemical \& Engineering Data, vol. 64, no. 3, pp. 944-951, 2019.

[13] J. Li, B. Li, and S. Gao, "Thermochemistry of hydrated potassium and sodium borates," The Journal of Chemical Thermodynamics, vol. 30, no. 4, pp. 425-430, 1998.

[14] Z. Liu, S. Li, and M. Hu, "Thermodynamic properties of $\mathrm{Cs}_{2}\left[\mathrm{~B}_{4} \mathrm{O}_{5}(\mathrm{OH})_{4}\right] \cdot 3 \mathrm{H}_{2} \mathrm{O}$," The Journal of Chemical Thermodynamics, vol. 37, no. 9, pp. 1003-1006, 2005.

[15] L. X. Zhu, T. Yue, S. Y. Gao, and S. P. Xia, "Thermochemistry of hydrated rubidium tetraborate," Journal of Chemical Thermodynamics, vol. 404, pp. 259-263, 2003.

[16] N. Penin, L. Seguin, B. Gérand, M. Touboul, and G. Nowogrocki, "Crystal structure of a new form of Cs $\left[\mathrm{B}_{5} \mathrm{O}_{6}(\mathrm{OH})_{4}\right] \cdot 2 \mathrm{H}_{2} \mathrm{O}$ and thermal behavior of $\mathrm{M}\left[\mathrm{B}_{5} \mathrm{O}_{6}(\mathrm{OH})_{4}\right]$. $2 \mathrm{H}_{2} \mathrm{O}(\mathrm{M}=\mathrm{Cs}, \mathrm{Rb}, \mathrm{Tl})$," Journal of Alloys and Compounds, vol. 334, no. 1-2, pp. 97-109, 2002.

[17] Y. E. Anderson, S. K. Filatov, I. G. Polyakova, and R. S. Bubnova, "Thermal behavior of $\mathrm{M}+\mathrm{B}_{5} \mathrm{O}_{6}(\mathrm{OH})_{4} \cdot 2 \mathrm{H}_{2} \mathrm{O}$ $(\mathrm{M}+=\mathrm{K}, \mathrm{Rb}, \mathrm{Cs})$ and polymorphic transformations of $\mathrm{CsB}_{5} \mathrm{O}_{8}, "$ Glass Physics and Chemistry, vol. 30, no. 5, pp. 450-460, 2004.

[18] Qinghai Institute of Salt Lakes of CAS, Analytical Methods of Brines and Salts, Chinese Science Press, Beijing, China, 2nd edition, 1988.

[19] J. G. Speight, Lange's Handbook of Chemistry, McGraw-Hill, New York, NY, USA, 16th edition, 2005. 